\title{
Efektifitas Pelayanan Penjualan Tiket Penyeberangan Dari Bangsal Menuju Tiga Gili
}

INFO ARTIKEL

\section{Riwayat Artikel:}

Diterima: $10-7-2018$

Disetujui: 11-7-2018

\section{Kata Kunci:}

1. Efektivitas

2. Pelayanan

3. Penjualan

4. Tiket
Keyword:
1. Effectiveness
2. Services
3. Sales
4. Tickets

\author{
Mardiah $^{1}$, Baiq Rhinelda ${ }^{2}$, Emi Junianti ${ }^{3}$ \\ 1Prodi Administrasi Publik, Universitas Muhammadiyah Mataram , Indonesia \\ ${ }^{2}$ Prodi Administrasi Bisnis, Universitas Muhammadiyah Mataram, Indonesia \\ 3Prodi Administrasi Publik, Universitas Muhammadiyah Mataram, Indonesia
}

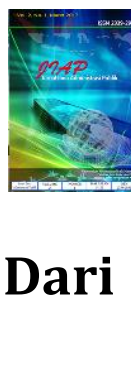




\section{Latar Belakang}

Dalam mengahadapi era globalisasi yang penuh dengan peluang dan tantangan, aparatur negara sebagai pelayan masyarakat yang memberikan pelayanan sebaik-baiknya menuju good governence. Pelayanan yang diberikan kepada masyarakat setiap waktu selalu menuntut pelayanan publik yang berkualitas dari birokrat yang dilakukan secara transparan dan akuntabilitas.

Sebagai sebuah lembaga, pelayanan publik menjamin keberlangsungan administrasi negara yang melibatkan pengembangan kebijakan pelayanan dan pengelolaan sumberdaya yang berasal dari dan untuk kepentingan publik. Sebagai profesi, pelayanan publik berpijak pada prinsip-prinsip profesionalisme dan etika seperti akuntabilitas, efektifitas, efisiensi, integritas, netralitas, dan keadilan bagi semua penerima pelayanan.

Pelayanan adalah bagian yang tidak bisa dipisahkan dari berbagai aspek kehidupan masyarakat khsususnya dalam meningkatkan kualitas dan kapabilitas yang terbaik sebagai suatu sistem pemerintahan yang baik. Pelayanan merupakan segala usaha atau kegiatan yang dilakukan seseorang atau sekelompok orang dalam rangka untuk memenuhi kebutuhan orang lain. Pelayanan publik merupakan salah satu tugas penting yang tidak dapat diabaikan oleh pemerintah daerah sebab jika komponen pelayanan terjadi stagnasi maka hampir dipastikan semua sektor akan berdampak kemacetan oleh sebab itu perlu ada perencanaan yang baik dan bahkan perlu diformulasikan standar pelayanan pada masyarakat sesuai dengan kewenangan yang diberikan oleh pemerintah pusat pada pemerintah daerah tanpa memeperhatikan struktur daerah ataupun jenis pelayanan di daerah tersebut. Misalnya dalam hal ini daerah pariwisata baik yang bertarap local maupun internasional.

Dalam konteks pelayanan di daerah wisata, tingkat kepuasan pelanggan sangat ditentukan oleh pelayanan yang baik yang didukung oleh prasana dan sumber daya manusia yang mempunyai kualitas dan kapabilitas yang baik pula. Hal ini, tentu tidak luput dari pantauan terhadap suatu daerah yang berada di daerah Nusa Tenggara Barat khususnya di bagian utara pantai Lombok Utara yang bernama pelabuhan bangsal.
Pelabuhan bangsal merupakan sebuah tempat dimana disediakan pelayanan penjualan tiket untuk menyeberang menggunakan boat kayu dari Lombok ke tiga gili matra (Gili Meno, Gili Air dan Gili Trawangan), pelabuhan Bangsal memiliki lokasi yang sangat strategis dimana berada tepat di jalur persimpangan untuk menampung para tamu baik dari jalan pusuk mongkey forest ataupun dari jalan raya Senggigi.

Kondisi geografis yang menunjang akan sangat memudahkan para tamu untuk berkunjung ke pulau gili melalui pelabuhan bangsal. Kondisi yang berada tepat disebuah teluk yang memungkinkan semua boat kayu dapat mendarat tepat dipinggir pantai tanpa harus khawatir dengan air pasang dan surut dan juga kondisi volume air yang rendah. Sehingga semua boat kayu akan mampu beroperasi setiap saat tanpa mengenal waktu dan kondisi air, adapun berbagai macam harga yang ditawarkan Dalam melakukan Penyeberangan ke pulau gili matra dengan berbagai macam tarif yang berlaku tahun 2017 Sebagai berikut :

1. Boat ke Gili Air : Rp. 12.000 per orang

2. Boat ke Gili Meno : Rp. 13.000 per orang

3. Boat ke Gili Trawangan : Rp. 15.000 per orang

Untuk speed boat atau fastboat diberlakukan harga Rp. 85.000,- per orang menuju Gili Trawangan. Adapun lama perjalanan menggunakan boat kayu terbilang cukup cepat hanya membutuhkan waktu 20 menit saja ke Gili Trawangan, 10 menit ke Gili Air dan 15 menit ke Gili Meno, hal ini dapat kita maklumi karena memang semua fasilitas mesin sudah di lengkapi dengan mesin 85 sampai dengan 100 PK dengan kapasitas penumpang 40 orang per boat sekali jalan.

Semua boat kayu yang beroperasi berada dalam naungan sebuah perusahaan yang telah memilki ijin pelayaran dan juga memegang asuransi jasa raharja sebagai sebuah referensi keselamatan lalu lintas. Pelabuhan Bangsal telah didirikan atas dasar pemberian pelayanan yang baik kepada para wisatawan dan pula sebagai penunjang ekonomi masyarakat terutama para nelayan yang beralih profesi sebagai pemilik kapal penumpang, secara tidak langsung pelabuhan bangsal telah menyerap banyak tenaga kerja dengan menempatkan orang-orang tertentu sebagai pemegang operasional. Untuk mengefesiensikan peran dan fungsi bagi masingmasing personal atau steak holder maka 
dibentuklah suatu koperasi yang bernama karya bahari.

Koperasi KARYA BAHARI merupakan pemegang saham terbesar atau sebagai tempat bernaungnya semua kapal kayu yang beroperasi. Namun setelah disurvey Koperasi Karya Bahari di pelabuhan Bangsal ternyata untuk kebutuhan transportasi laut, yakni tempat penjualan tiket kapal Penyeberangan masih menggunakan cara sederhana, yakni para pembeli tiket harus menyiapkan uang untuk setiap kali pembelian tiket serta petugas masih mencatat nama penumpang dengan pena dan kertas.Koperasi Karya Bahari memiliki jumlah karyawan 100 orang baik yang bertugas dalam loket penjualan tiket maupun yang bertugas sebagai boatman.Jumlah kapal untuk Penyeberangan sebanyak 52 kapal kayu dimana setiap kapal dipegang oleh satu orang boatman.Pada pelabuhan bangsal terdapat 2 loket tempat penjualan tiket,untuk jalur Penyeberangan ke Gili Trawangan dan Gili Meno satu jalur dan ditugaskan sebanyak lima orangkaryawan dan satu loket penjualan tiket khusus untuk Penyeberangan ke Gili Air ditugaskan dua orang karyawan.Setiap karyawan yang bekerja pada Koperasi Karya Bahari dilakukan dengan cara pergantian jadwal kerja antara karyawan yang satu dengan karyawan yang lainnya baik pada loket penjualan tiket dipelabuhan bangsal maupun loket penjualan tiket yang berada di tiga gili tersebut sesuai dengan peraturan dan jadwal kerja yang telah ditetapkan.

Pada koperasi Karya Bahari telah disediakan:

1. Konter ticket yang siap melayani penumpang dari pukul 07.00 pagi hingga pukul 05.00 sore yang setiap satu orang penumpang dilayani kurang lebih lima menit oleh setiap karyawan yang berada pada Koperasi Karya Bahari.

2. Adanya porter sebagai bagian dari pelayanan akan tetapi anda harus mengeluarkan uang lebih untuk meminta jasa porter dalam membawa barang bawaan and porter membawa baran a, perlu diingat bahwa biaya boat tidak termasuk dalam jasa porter, jadi sebelum $g$ anda maka negoisasi harga terlebih dahulu demi menghindari kesalahpahaman nanti.

3. Life jacket yang sudah tersedia di atas kapal kayu dengan jumlah melebihi jumlah penumpang yang ada.

4. Hingga saat ini Koperasi Karya Bahari telah banyak menyumbangkan dana berupa pajak pendapatan yang secara tidak langsung membantu dalam meningkatkan otonomi daerah ke arah yang lebih baik.

\section{Tinjauan Pustaka}

\section{a. Teori Efektivitas}

Efektivitas memiliki arti berhasil atau tepat guna. Efektif merupakan kata dasar, sementara kata sifat dari efektif adalah efektivitas. Menurut Effendy (1989) mendefinisikan efektivitas sebagai berikut: "Komunikasi yang prosesnya mencapai tujuan yang direncanakan sesuai dengan biaya yang dianggarkan, waktu yang ditetapkan dan jumlah personil yang ditentukan" (Effendy, 1989:14).

Efektivitas menurut pengertian di atas mengartikan bahwa indikator efektivitas dalam arti tercapainya sasaran atau tujuan yang telah ditentukan sebelumnya merupakan sebuah pengukuran dimana suatu target telah tercapai sesuai dengan apa yang telah direncanakan. Pengertian lain menurut Susanto, "Efektivitas merupakan daya pesan untuk mempengaruhi atau tingkat kemampuan pesan-pesan untuk mempengaruhi" (Susanto, 1975:156). Menurut pengertian Susanto diatas, efektivitas bisa diartikan sebagai suatu pengukuran akan tercapainya tujuan yang telah direncanakan sebelumnya secara matang.

Menurut pendapat Mahmudi dalam bukunya Manajemen Kinerja Sektor Publik mendefinisikan efektivitas, sebagai berikut:

"Efektivitas merupakan hubungan antara output dengan tujuan, semakinbesar kontribusi (sumbangan) output terhadap pencapaian tujuan, makasemakin efektif organisasi, program atau kegiatan" (Mahmudi, 2005:92). Efektivitas berfokus pada outcome (hasil), program, atau kegiatan yang dinilai efektif apabila output yang dihasilkan dapat memenuhi tujuan yang diharapkan atau dikatakan spending wisely.

Sehubungan dengan hal tersebut di atas, maka efektivitas adalah menggambarkan seluruh siklus input, proses dan output yang mengacu pada hasilguna daripada suatu organisasi, program atau kegiatan yang menyatakan sejauh mana tujuan (kualitas, kuantitas, dan waktu) telah dicapai, serta ukuran berhasil tidaknya suatu organisasi mencapai tujuannya dan mencapai target-targetnya. 
Hal ini berarti, bahwa pengertian efektivitas yang dipentingkan adalahsemata-mata hasil atau tujuan yang dikehendaki. Pandangan yang sama menurut pendapat Peter F. Drucker yang dikutip H.A.S. Moenir dalam bukunya Manajemen Pelayanan Umum di Indonesia yang mendefinisikan efektivitas, sebagai berikut efektivitas, pada sisi lain, menjadi kemampuan untuk memilih sasaran hasil sesuai. Seorang manajer efektif adalah satu yang memilih kebenaran untuk melaksanakan" (Moenir, 2006:166). Memperhatikan pendapat para ahli di atas, bahwa konsep efektivitas merupakan suatu konsep yang bersifat multidimensional, artinya dalam mendefinisikan efektivitas berbeda-beda sesuaiterintegrasinya sasaran dan kegiatan organisasi secara menyeluruh, kemampuan adaptasi dari organisasi terhadap perubahan lingkungannya. Mengaju pada penjelasan diatas, maka untuk mencapai tujuan organisasi secara efektif perlu adanya harmonisasi kemampuan sumberdaya dengan menggunakan sarana yang lain sehingga sasaran yang akan dacapai menjadi jelas. Pencapaian sasaran tersebut dapat dikatakan efektif apabila adanya keharmonisan. Setiap pekerjaan pegawai dalam organisasi sangat sangat menentukan bagi pencapaian hasil kegiatan seperti yang telah direncanakan terlebih dahulu. Untuk itu faktor keefektifannya banyak mempengaruhi kepada kemampuan aparatur dan organisasi dalam melaksanakan tugas dan kewenangannya. Tingkat pencapaiantujuan aparatur dalam suatu organisasi dikatakan efektif apabila pencapaian itu sesuai dengan tujuan organisasi dan memberikan hasil yang bermanfaat.

Menurut beberapa ahli mengemukakan pendapatnya tentang efektivitas antara lain:

McDonald dan Lawton (1997) dalam Ratminto dan Winarsih (2010:174) mengemukakan bahwa efektivitas adalah tercapainya tujuan yang telah ditetapkan, baik itu dalam bentuk target, sasaran jangka panjang dan misi organisasi. Definisi efektivitas menurut Ratminto dan Winarsih (1997:174) adalah tercapainya tujuan yang telah ditetapkan, baik itu dalam bentuk target,sasaran jangka panjang maupun misi organisasi, akan tetapi pencapaian tujuan ini harus juga mengacu pada visi organisasi.

Konsep tingkat efektivitas organisasi menunjuk pada tingkat jauh organisasi melaksanakan kegiatan atau fungsinya sehingga tujuan yang telah ditetapkan dapat tercapai dengan menggunakan alat-alat dan sumber daya yang ada secara optimal. Konsep efektivitas organisasi meliputi dua aspek yaitu: tujuan organisasi dan pelaksanaan fungsi atau cara untuk mencapai tujuan tersebut. Selanjutnya Gibson dalam Waluyo (2007 :89), menjelaskan lima kategori umum kriteria keefektifan mulai dengan dimensi waktu jangka pendek yaitu:

Kriteria produksi, mencerminkan kemampuan organisasi untuk menghasilkan jumlah dan kualitas keluaran yang dibutuhkan lingkungn.

Kriteria efisiensi, perbandingan keluaran tesrhadap masukan yang mengacu pada ukuran pengguna sumberdaya yang langka dalam organisasi.

Kriteria kepuasan, adalah ukuran keberhasilan organisasi dalam memenuhi kebutuhan karyawan dan anggotanya termasuk pelanggan.

Kriteria keadaptasian, tingkat dimana organisasi dapat dan benar-benar tanggap terhadap perubahan internal.

Kriteria pengembangan,mengukur kriteria organisasi untuk meningkatkan kafasitasnya menghadapi lingkungan.

Kriteria dalam pengukuran efektivitas organisasi menurut Steers dalam Makmur Syarif (2008: 125) sebagai berikut: 1. Produktivitas, 2. Kemampuan adaptasi atau fleksibilitas, 3. Kepuasan kerja, 4. Kemampuan berlaba, 5. Pencarian sumber daya.

Menurut Makmur (2011: 7) dari segi kriteria efektivitas, unsur-unsurnya antara lain:1) Ketepatan penentuan waktu, 2) Ketepaan perhitungan biaya, 3) Ketepatan dalam pengukuran, 4) Ketepatan dalam menentukan pilihan, 5) Ketepatan berpikir, 6) Ketepatan dalam melakukan perintah, 7) Ketepatan dalam menentukan tujuan, 8) Ketepatan dalam sasaran.

Dari beberapa pengertian teori efektivitas yang telah dikemukakan diatas, maka dalam penelitian ini peneliti dapat menyimpulkan bahwa efektivitas merupakan ukuran yang digunakan oleh organisasi dalam mencapai tujuan organisasi yang sesuai dengan target, visi maupun misi organisasi yang telah ditetapkan. 


\section{b. Teori Pelayanan Publik}

Pelayanan publik tidak terlepas dari masalah kepentingan umum, yang menjadi asal-usul timbulnya istilah pelayanan publik. tentunya memberikan pelayanan terbaik kepada publik atau masyarakat. Sebelum menjelaskan lebih lanjut mengenai pelayanan publik, maka peneliti akan menguraikan terlebih dahulu pengertian pelayanan.

Menurut Ratih Huriyati yang dikutip dari Zeithaml dan Bitner dari bukunya yaitu Service Marketing mengemukakan bahwa :

"Pelayanan adalah seluruh aktivitas ekonomi dengan output selain produk dalam pengertian fisik, dikonsumsi dan diproduksi pada saat bersamaan, memberikan nilai tambah dan secara prinsip tidak berwujud (intangible) bagi pembeli pertamanya" (Huriyati, 2005: 28).

Berdasarkan dari definisi diatas dapat dikemukakan bahwa pada dasarnya pelayanan adalah sesuatu yang tidak berwujud tetapi dapat memenuhi kebutuhan pelanggan atau masyarakat. Pelayanan tidak dapat mengakibatkan peralihan hak atau kepemilikan dan terdapat interaksi antara penyedia jasa dengan pengguna jasa. Pelayanan merupakan suatu kegiatan yang dilakukan oleh seseorang atau kelompok dalam memberikan kepuasan kepada yang menerima pelayanan. Pelayanan hakekatnya adalah serangkaian kegiatan, karena itu pelayanan merupakan proses. Pelayanan sebagai proses berlangsung secara rutin dan berkesinambungan meliputi seluruh kehidupan orang dalam masyarakat.

Pendapat lain mengenai definisi pelayanan publik dikemukakan oleh Moenir sebagai: "kegiatan yang dilakukan oleh seseorang atau sekelompok orang dengan landasan faktor materil melalui sistem, prosedur, dan metode tertentu dalam rangka usaha memenuhi kepentingan orang lain sesuai dengan haknya.Sejalan dengan pendapat tersebut, Sadu Wasistiono mengemukakan bahwa:

"Pelayanan publik adalah pemberian jasa baik oleh pemerintah, pihak swasta atas nama pemerintah ataupun pihak swasta kepada masyarakat, dengan atau tanpa pembayaran guna memenuhi kebutuhan dan atau kepentingan masyarakat" (Wasistiono, 2001:51-52).
Berdasarkan kedua pendapat di atas bahwa pelayanan publik itu diselenggarakan sesuai dengan sistem atau prosedur dan bukan hanya diberikan instansi atau lembaga pemerintah saja, melainkan juga diberikan oleh pihak swasta. Kegiatan pelayanan publik yang diselenggarakan pemerintah untuk masyarakat meliputi banyak hal, yaitu yang menyangkut semua kebutuhan masyarakat baik berupa barang maupun jasa. Hal ini sejalan dengan pendapat Pamudji bahwa:

"Jasa pelayanan pemerintah yaitu berbagai kegiatan yang bertujuan memenuhi kebutuhan masyarakat akan barang-barang dan jasa-jasa, jenis pelayanan publik dalam arti jasa-jasa, yaitu seperti pelayanan kesehatan, pelayanan keluarga, pelayanan pendidikan, pelayanan pencarian keadilan" (Pamudji, 1994:21-22).

Berdasarkan pendapat di atas, jasa pelayanan yang diberikan oleh pemerintah kepada masyarakat yaitu berbagai kegiatan yang bertujuan untuk memenuhi kebutuhan masyarakat akan barang-barang dan jasa-jasa, jenis pelayanan publik dalam arti jasa-jasa yaitu seperti pelayanan kesehatan, pelayanan pendidikan, pelayanan keluarga, serta pelayanan administrasi.

\section{c. Standar Pelayanan Publik}

Menurut Wasistiono (Hardiyansyah (2011:28) menyatakan setiap penyelenggaraan pelayan, sebagai jaminan adanya kepastian bagi pemberi didalam pelaksanaan tugas dan fungsinya dan bagi penerima pelayanan dalam proses pengajuan permohonannya dan standar pelayanan merupakan ukuran yang dibakukan dalam penyelenggaraan pelayanan publik sebagai pedoman yang wajib ditaati dan dilaksanakan oleh penyelenggara pelayanan, dan menjadi pedoman bagi penerima pelayanan dalam proses pengajuan permohonan, serta sebagai alat kontrol masyarakat dan/atau penerima layanan atas kinerja penyelenggara pelayanan. Dalam Peraturan Menteri Pendayagunaan Aparatur Negara (MenPAN) dan Reformasi Birokrasi Nomor 16 Tahun 2014, tentang pedoman survei kepuasan masyarakat terhadap penyelanggaraan pelayanan publik yang meliputi:

1. Persyaratan

Persyaratan adalah syarat yang harus dipenuhi dalam pengurusan suatu jenis pelayanan, baik persyaratan teknis maupun administrative. 
2. Prosedur

Prosedur adalah tata cara pelayanan yang dibakukan bagi pemberi dan penerima pelayanan, termasuk pengaduan.

a. Waktu Pelayanan

Waktu pelayanan adalah jangka waktu yang diperlukan untuk menyelesaikan seluruh proses pelayanan dari setiap jenis pelayanan.

b. Biaya/Tarif

Biaya/tarif adalah ongkos yang dikenakan kepada penerima layanan dalam mengurus dan/atau memperoleh pelayanan dari penyelenggara yang besarnya ditetapkan berdasarkan kesepakatan antara penyelenggara dan masyarakat.

c. Produk Spesifikasi Jenis Pelayanan

Produk spesifikasi jenis pelayanan adalah hasil pelayanan yang diberikandan diterima sesuai dengan ketentuan yang telah ditetapkan. Produk pelayanan ini merupakan hasil dari setiap spesifikasi jenis pelayanan.

d. Kompetensi Pelaksana

Kompetensi pelaksana adalah kemampuan yang harus dimiliki oleh pelaksana meliputi pengetahuan, keahlian, keterampilan, dan pengalaman.

e. Perilaku Pelaksana

Perilaku pelaksana adalah sikap petugas dalam memberikan pelayanan.

f. Maklumat Pelayanan

Maklumat pelayanan adalah merupakan pernyataan kesanggupan dan kewajiban penyelenggara untuk melaksanakan pelayanan sesuai dengan standar pelayanan.

g. Penanganan Pengaduan, Saran dan

Masukan

Penanganan pengaduan, saran dan masukan adalah tata cara pelaksanaan penanganan pengaduan dan tindak lanjut.

Dalam Ratminto dan Winarsih (2010: 182) Zeinthml, Parasuraman, dan Berry menjelaskan bahwa pengukuran kinerja pelayanan dapat dilakukan dengan menggunakan beberapa indikator kinerja pelayanan, yaitu:1. Kemampuan fisik (Tangible,) 2. Reliabilitas (Reliability), 3. Responsivitas (Responsiveness), 4. Kompetensi (Competence), 5. Kesopanan (Courtesy), 6. Kredibilitas (Credibility), 7. Keamanan (Security), 8. Akses (Acces),9.
Komunikasi (Communication), 10. Pengertian (Understanding the customer)

\section{Metode Penelitian}

Penelitian ini adalah penelitian kualitatif dengan pendekatan deskriptif. Penelitian kualitatif adalah penelitian yang bermaksud untuk memahami fenomena tentang apa yang dialami oleh subjek penelitian secara holistik, dan dengan cara deskripsi dalam bentuk katakata dan bahasa pada suatu konteks khusus yang alamiah dan dengan memanfaatkan berbagai metode alamiah (Moleong, 2011:6).

Penelitian ini dilaksanakan pada Kantor Koperasi Karya Bahari Bangsal Kecamatan Pemenang Kabupaten Lombok Utara.

Sumber data dalam penelitian ini adalah data primer yang merupakan data yang diperoleh dari hasil pengamatan langsung (observasi) dengan pihak-pihak terkait. Dalam hal ini pegawai Kantor Koperasi Karya Bahari Bangsal Kecamatan Pemenang Kabupaten Lombok Utara Untuk mengumpulkan data yang dibutuhkan dalam penulisan ini maka digunakan pengumpulan data sebagai berikut :

1. Penelitian Lapangan (Field Research)

a. Pengamatan (Observasi)

b. Wawancara (Interview)

Teknik analisa data yang digunakan dalam penelitian ini adalah analisis data kualitatif, mengikuti konsep yang diberikan Miles dan Huberman. Miles dan Huberman dan Saldana (2014), mengemukakan bahwa aktifitas dalam analisis data kualitatif dilakukan secara interaktif dan berlangsung secara terus menerus pada setiap tahapan penelitian sehingga sampai tuntas, dan datanya sampai jenuh. Aktivitas dalam analisis data, yaitu data reduction, data display, data reduction, dan conclusion drawing/verification.

\section{Hasil dan Pembahasan}

a. Efektivitas Pelayanan Penjualan Tiket Penyeberangan dari Bangsal Menuju Tiga Gili (Studi Pada Koperasi Karya Bahari Bngsal Kecamatan Pemenang Kabupaten Lombok Utara)

Berdasarkan hasil penelitian penulis mencoba menganalisis efektivitas pelayanan penjualan tiket Penyeberangan menuju tiga gili berdasarkan persepsi dari beberapa narasumber yang sudah 
penulis wawancarai dengan mengajukan beberapa pertanyaan secara terstruktur. Efektivitas pelayanan penjualan tiket Penyeberangan dapat diukur berdasarkan indikator-indikator yang dapat menunjang keberhasilan pelayanan publik yaitu Reliability (kemampuan organisasi untuk memberikan pelayanan sesuai yang dijanjikan secara akurat dan terpercaya.), Tangible (kemampuan suatu perusahaan dalam menunjukkan eksistensinya kepada pihak eksternal. Penampilan dan kemampuan sarana dan prasarana fisik perusahaan dan keadaan lingkungan sekitarnya adalah bukti nyata dari pelayanan yang diberikan oleh pemberi jasa), Responsiviness (kemampuan untuk membantu dan memberikan pelayanan yang cepat (responsif) dan tepat kepada pelanggan, dengan penyampaian informasi yang jelas. Membiarkan konsumen menunggu tanpa adanya suatu alasan yang jelas menyebabkan persepsi negatif dalam kualitas pelayanan), Assurance (pengetahuan, kesopansantunan, dan kemampuan para pegawai perusahaan untuk menumbuhkan rasa percaya para pelanggan kepada perusahaan)dan Empathy (memberikan perhatian yang tulus dan bersifat individual atau pribadi yang diberikan kepada para pelanggan dengan berupa memahami keinginan konsumen). (Zeithhaml, Parasuraman \& Berry (dalam Hardiansyah 2011:46)

\subsubsection{Reliability atau Keandalan}

Reliability atau Keandalan Merupakan Pelayanan Dengan Tepat Dan Benar dimana dimensi ini merujuk pada kemampuan untuk menghantarkan layanan sesuai seperti yang telah dijanjikan tanpa suatu kesalahan (konsisten) serta akurat.

Reability juga merupakan kemampuan organisasi untuk memberikan pelayanan sesuai yang dijanjikan secara akurat dan terpercaya. Kinerja harus sesuai dengan harapan pelanggan yang berarti ketepatan waktu, pelayanan yang sama untuk semua pelanggan tanpa kesalahan, sikap yang simpatik, dan dengan akurasi yang tinggi. "Dalam pelayanan penjualan tiket Penyeberangan pada koperasi karya bahari di Pelabuhan Bangsal telah didirikan atas dasar pemberian pelayanan yang tepat dan benar baik kepada para wisatawan asing maupun wisatawan mancanegara dan sebagai penunjang ekonomi masyarakat terutama para nelayan yang beralih profesi sebagai pemilik kapal penumpang, secara tidak langsung pelabuhan bangsal telah menyerap banyak tenaga kerja dengan menempatkan orang-orang tertentu sebagai pemegang operasional..Berdasarkan hasil wawancara mengenai, Bagaimanakah menurut anda mengenai pelayanan tiket pada koperasi karya bahari?

Ibu Maria selaku pelanggan tiket pada koperasi Karya Bahari mengatakan :

"Kalau menurut saya pelayanan pada koperasi karya bahari itu bisa dikatakan cukup memuasakan karena staf atau karyawannya cukup ramah dan sopan dalam melayani saya sebagai salah satu pelanggan tiket disini". (Wawancara Pada tanggal 15-04-2018)

Pernyataan serupa juga diungkapkan oleh ibu noviana selaku pelanggan tiket pada koperasi karya bahari:

"Dalam Pelayanan yang diberikan oleh koperasi karya bahari dimana para pegawai di sana sangat ramah, dan gesit dalam melayani kami sehingga saya merasa nyaman dalam membeli tiket, dan disana tersedia fasilitas yang nyaman untuk kami para pelanggan tiket penyeberangan". (Wawancara pada tanggal 15-04-2018)

Hal tersebut juga selaras dengan pernyataan yang diungkapkan oleh Bapak Suryadi selaku pelanggan tiket pada koperasi karya bahar Berdasarkan hasil wawancara, Bagaimanakah perasaan anda saat diberikan pelayanan oleh para staf atau pegawai pada koprasi karya bahari? mengatakan :

"Saya merasa sangat puas dengan pelayanan yang diberikan,staf atau karyawan yang melayani saya dengan sepenuh hati tanpa membeda-bedakan pelanggannya." (Wawancara pada tanggal 15-042018)

Dari pernyataan ketiga narasumber diatas menunjukkan bahwa pelayanan yang diberikan koperasi karya bahari mendapat respon positif oleh masyarakat yang menggunakan jasa pelayanan 
koperasi karya bahari dalam hal ini ialah penyeberangan antar pulau.

Koperasi karya bahari telah melakukan upaya pemberian pelayanan yang terbaik, pelayanan adalah suatu aktivitas atau serangkaian aktivitas yang bersifat tidak kasa mata (tidak dapat diraba yang terjadi sebagai akibat adanya interaksi konsumen dengan karyawan atau hal-hal lain yang disediakan oleh persahaan pemberi pelayanan yang diaksudkan untuk memecahkan permasalahan konusmen atau pelanggan (Gronroos 1990 dalam Ratminto dan Winarsih) (2010:2).

Dengan memberikan pelayanan yang tepat baik itu dari pelayanan administrasi maupun fasilitas yang menujang bagi pelanggan. Para pegawai koperasi karya bahari telah diberikan arahan oleh atasan untuk memberikan pelayanan yang maksimal sesuai dengan visi dan misi dari koperasi karya bahari itu sendiri, sehingga tujuan dan harapan yang dicita-citakan bersama akan tercapai. Hal tersebut dapat dilihat dari pelayanan yang ramah, dan gesit dalam memberikan pelayanan bagi pelanggan itu sendiri.

\section{Tangibles atau Bukti Fisik}

Tangibles atau Bukti Fisik yaitu Penyedia yang memadai,sumber daya manusia dan sumber daya lainnya. Merupakan kemampuan suatu perusahaan dalam menunjukkan eksistensinya kepada pihak eksternal. Penampilan dan kemampuan sarana dan prasarana fisik perusahaan dan keadaan lingkungan sekitarnya adalah bukti nyata dari pelayanan yang diberikan oleh pemberi jasa. Yang meliputi fasilitas (gedung, dan lain sebagainya), perlengkapan dan peralatan yang digunakan (teknologi), serta penampilan pegawainya. Dalam konteks pelayanan dideaerah wisata tepatnya pada koperasi karya bahari bahwa tingkat kepuasan para pelanggan sangat ditentukan oleh pelayanan yang baik yang didukung oleh sarana dan sumber daya manusia yang mempunyai kualitas dan kapabilitas yang baik .

Tangible yang baik akan mempengaruhi persepsi pelanggan. Pada saat yang bersamaan aspek tangible ini juga merupakan salah satu sumber yang mempengaruhi harapan pelanggan. Karena tangible yang baik, maka harapan responden menjadi lebih tinggi., maka harapan terhadap pelayanan yang lain akan baik. Mereka berharap para pelayannya memberikan pelayanan cepat. Karena suatu service tidak bisa dilihat, tidak bisa dicium dan tidak bisa diraba, maka aspek tangible menjadi penting sebagai ukuran terhadap pelayanan. Pelanggan akan menggunakan indera penglihatan untuk menilai suatu kualitas pelayanan.

Hal ini tentu saja tidak luput dari pantauan terhadap suatu daerah yang berada di Nusa Tenggara Barat khususnya di bagian utara pantai Lombok utara yang bernama pelabuhan bangsal tempat dimana penjualan tiket Penyeberangan tersebut.

Hal tersebut sesuai dengan pernyataan yang dikemukakan oleh Bapak Karim selaku pelanggan tiket pada koperasi karya bahari Berdasarkan hasil wawancara, Bagaimanakah menurt anda pasilitas yang ada pada koprasi karya bahari ? mengatakan:

"Menurut saya sarana dan prasarana yang disediakan dikoperasi ini cukup memadai,terlihat dari bangunan gedung yang luas,bersih serta terjaga keamanan dan kenyamanannya,apalagi ditambah dengan adanya TV dan tempat duduk, jadinya saya bisa menonton untuk menunggu pemberangkatan boat." (Wawancara pada tanggal 19-04-2018)

Pernyataan serupa juga diungkapkan oleh Ibu Rohana selaku pelanggan tiket pada koperasi karya bahari Berdasarkan hasil wawancara apakah anda puas dengan fasilitas yang ada pada koprasi karya bahari? mengatakan :

"Saya sangat senang membeli tiket pada koperasi karya bahari ini karena ruangannya tidak panas, ada AC apalagi sudah tersedia jaringan wafi gratis.jadi saya tidak bosan menunngu waktu pemberangkatan boatanya" (Wawancara pada tanggal 19-04-2018)

Hal ini juga didukung oleh pernyataan yang disampaikan oleh Icha selaku pelanggan tiket pada koperasi karya bahari mengatakan :

"Saya puas dengan adanya mushola dan toilet yang disediakan, karena toiletnya bersih dan wangi jarang sekali saya melihat ada toilet umum yang bersih dan wangi." (Wawancara pada tanggal 1904-2018) 
Dari penyataan ketiga informan diatas menunjukkan bahwa penampilan dan kemampuan sarana dan prasarana fisik perusahaan dan keadaan lingkungan sudah sangat terlihat dan nyata dari pelayanan yang diberikan oleh koperasi karya bahari. Hal ini menunjukan bahwa koperasi karya bahari memberikan fasilitas yang cukup memadai kepada pelanggan.

Bapak Lalu Zaenal Abidin selaku pegawai pada koperasi karya bahari Berdasarkan hasil wawancara, Apakah sumber daya yang ada pada koprasi karya bahari telah cukup atau masih kurang ? mengatakan:

"Sumber daya manusia pada koperasi karya bahari masih memiliki kendala pada setiap posisi yang diemban masing-masing,karena dalam penempatan posisi pada koperasi karya bahari ini tidak sesuai dengan bidang yang kita miliki, ini disebabkan karena kekurangan pegawai”. (Wawancara pada tanggal 21-04-2018)

Pernyataan serupa juga diungkapkan oleh Bapak Muludin selaku sekertaris pada koperasi karya bahari mengatakan:

"Pada saat ini perusahaan kami kekuangan sumber daya manusia sehingga terkadang kita menggunakan tenaga pembantu tambahan dalam melaksanakan tugas, biasanya ini terdapat pada bidang keamanan dan ketertiban." (Wawancara pada tanggal 21-04-2018)

Dari pernyataan kedua narasumber diatas menunjukkan bahwa sumber daya manusia pada koperasi karya bahari sedikit mengalami kesulitan dalam melaksanakan tugas sehingga dalam memberikan pelayanan tidak menjadi begitu efektif karena keterbatasan sumber daya tersebut.

Sehingga diharapkan dalam melaksanakan roda perusahaan koperasi karya bahari perlu melakukan penambahan karyawan mereka agar tercapainya visi dan misi koperasi karya bahari tersebut.penambahan itu juga tidak luput dengan pelatihan dan pembinaan sehingga memperoleh pegawai atau karyawan yang profesional dalam melaksanakan pekerjaan.

Responsiviness atau Ketanggapan (Keinginan melayani Konsumen Dengan Cepat)
Sebagai keinginan untuk membantu (willingness to help), bagaimana memberikan layanan yang cepat dan menangani masalah atau komplain dengan baik. Sebuah istilah lain yang sering kita dengar adalah tanggap terhadap kebutuhan pelanggan. Sebagaimana sifat manusia yang pada umumnya senang apabila diperhatikan, dilayani dengan cepat dan dibantu pada saat mengalami masalah, maka responsiveness yang dimaksudkan disini adalah pengukuran mengenai ketiga hal tersebut di atas.

Merupakan suatu kemampuan untuk membantu dan memberikan pelayanan yang cepat (responsif) dan tepat kepada pelanggan, dengan penyampaian informasi yang jelas. Membiarkan konsumen menunggu tanpa adanya suatu alasan yang jelas menyebabkan persepsi negatif dalam kualitas pelayanan.kualitas pelayanan dibangun atas perbandingan dua faktor utama,yaitu persepsi pelanggan atas layanan yang mereka terima dengan layanan yang sesungguhnya diharapkan. Responsiveness (tanggap) adalah adanya keinginan untuk menolong konsumen dan menyediakan kecepatan dan ketepatan pelayanan. Harapan pelanggan terhadap kecepatan pelayanan hampir dapat dipastikan akan berubah yang kecendrungannya naik dari waktu ke waktu. Dalam bahasa ekonomi waktu adalah "scarce resources". Karena itu waktu sama dengan uang yang harus digunakan secara bijak. Itulah sebabnya pelanggan merasa tidak puas apabila waktunya terbuang secara percuma karena dia sudah kehilangan kesempatan lain untuk memperoleh sumber ekonomi. Pelanggan bersedia untuk mengorbankan atau membayar pelayanan yang lebih mahal untuk setiap waktu yang dapat dihemat.

Jika kenyataannya lebih dari yang diharapkan maka layanan dapat dikatakan berkualitas, dan sebaliknya. Singkat kata, kualitas pelayanan dapat di definisikan sebagai seberapa jauh perbedaaan antara kenyataan dan harapan pelayanan pelanggan yang mereka terima.responsiveness juga dapat diartikan sebagai respons atau kesigapan karyawan dalam membantu pelanggan dalam memberikan pelayanan yang cepat dan tanggap, yang meliputi kesigapan karyawan dalam melayani pelanggan, 
kecepatan karyawan dalam menangani transaksi dan menangani keluhan pelanggan.

Assurance atau jaminan dan kepastian (Tingkat Perhatian Terhadap Etika Dan Moral Dalam Memberikan Pelayanan)

Merupakan pengetahuan, kesopansantunan, dan kemampuan para pegawai perusahaan untuk menumbuhkan rasa percaya para pelanggan kepada perusahaan. Dalam memberikan pelayanan administrator perlu juga memperhatikan etika dalam memberikan pelayanan ini akan dapat mempengaruhi efektivitas dari perusahaan itu sendiri karena pelayanan yang baik salah satunya adalah melihat perilaku dari administror itu sendiri. Salah satu yang dapat ditangkap oleh pelanggan adalah etika dalam memberikan pelayanan yang ditunjukkan oleh pemberi layanan. Mengingat dampaknya yang cukup hebat dalam menggaet pelanggan, maka para pemilik usaha harus memberikan perhatian dan pelatihan yang memadai kepada Customer Service sebagai garda terdepan untuk mendukung kemajuan usaha mereka.

Memberikan layanan yang cepat dan menangani masalah atau komplain dengan baik. Sebuah istilah lain yang sering kita dengar adalah tanggap terhadap kebutuhan pelanggan. Sebagaimana sifat manusia yang pada umumnya senang apabila diperhatikan, dilayani dengan cepat dan dibantu pada saat mengalami masalah, maka responsiveness yang dimaksudkan disini adalah pengukuran mengenai ketiga hal tersebut di atas.

Dalam mewujudkan etika yang baik dalam pemberikan pelayanan dipengaruhi dua faktor. Faktor pertama, yaitu faktor manusia yang memberikan pelayanan tersebut. Manusia (karyawan) yang melayani Pelanggan harus memiliki kemampuan melayani Pelanggan secara tepat dan cepat. Di samping itu, karyawan harus memiliki kemampuan dalam berkomunikasi, sopan santun, ramah dan bertanggung jawab penuh terhadap Pelanggan, serta memiliki pengetahuan dan kemampuan yang baik dalam memahami kebutuhan Pelanggan.

Faktor kedua dalam memberikan pelayanan yang terbaik juga harus diikuti oleh tersedianya sarana dan prasarana yang mendukung kecepatan, ketepatan, dan keakuratan pekerjaan. Prasarana dan sarana yang dimiliki harus didukung oleh kemajuan teknologi terkini dan teknologi ini juga harus dioperasikan oleh manusia yang berkualias pula.dalam koperasi klarya bahari menunjukkan hal yang selarasa dari teori diatas.

Hal ini diungkapkan oleh Ridwan selaku pelanggan tiket pada koperasi karya bahari berdasarkan hasil wawancara, Bagaimanakah menurt anda etika para pegawai pada koprasi karya bahari ? mengatakan:

"Saya senang dengan pelayanan yang diberikan oleh para pegawai koperasi karya bahari, mereka melayani dengan ramah ramah dan sopan" (25-04-2018)

Hal serupa juga diungkapkan oleh Ibu Marini selaku pelanggan tiket mengatakan :

"Saya cukup puas dalam pelayanan yang diberikan oleh pegawai disana mereka memiliki etika dan sopan santun saat memberikan pelayanan." (Wawancara pada tanggal 25-04-2018)

Bapak Saipul selaku pelanggan tiket pada koperasi karya bahari mengatakan:

"Etika para pegawai koperasi karya bahari sudah cukup baik, mereka diberikan pakaian seragam yang bagus, sehinngga kita enak dilihat dan pandang." (Wawancara pada tanggal 25-042018)

Berdasarkan pemaparan narasumber diatas terlihat bahwa dalam memberikan pelayanan koperasi karya bahari menujukkan etika yang baik dalam melaksanakan tugas ini terlihat dari cara mereka berpakaian dan bagaimana para pegawai berintraksi dengan pelanggan dan juga bagaimana mereka merespon atau menunjukkan sikap yang baik.

Kemudian sebuah pekerjaan dikatakan professional apabila pekerjaan tersebut memiliki kode etik. Kode etik adalah sumber etika, aturan, sopan santun atau tata susila, atau suatu hal yang berhubungan dengan kesusilaan dalam mengerjakan suatu pekerjaan. Kode etik profesi berarti aturan kesusilaan suatu profesi. Artinya sebagai penangkal dari kecenderungan manusia pengemban profesi 
yang ingin menyimpang/ menyeleweng. Kode etik berfungsi: memberikan pedoman bagi setiap anggota profesi tentang prinsip profesionalitas yang telah digariskan, sebagai control social bagi masyarakat atas profesi yang bersangkutan, mencegah campur tangan pihak dari luar organisasi profesi tentang hubungan etika keanggotaan profesi.

Dalam lapangan kerja, atasan seharusnya menilai kemampuan orang bukan senantiasa atas diploma atau gelarnya, tetapi atas dasar kesanggupannya untuk mewujudkan prestasi berupa dengan modal pengetahuan yang ada. Diploma atau sarjana bukan jaminan prestasi seseorang. Prestasi harus diukur di satu pihak dengan hasil yang diperoleh dari seseorang dan dilain pihak dengan tolak ukur yang dikaitkan dengan kemampuan yang semestinya ada pada orang itu.

4.3.1.5 Empathy (Tingkat Kemampuan Untuk Mengetahui Kenginan Dan Kebutuhan Konsumen)

Yaitu memberikan perhatian yang tulus dan bersifat individual atau pribadi yang diberikan kepada para pelanggan dengan berupa memahami keinginan konsumen. Di mana suatu koperasi diharapkan memiliki pengertian dan pengetahuan tentang pelanggan, memahami kebutuhan pelanggan secara spesifik, serta memiliki waktu pengoperasian yang nyaman bagi pelanggan. Seperti diketahui, kebutuhan dan keinginan langganan/ konsumen mempunyai keanekaragaman serta mempunyai banyak tingkatan pula. Oleh karena itu, di dalam melaksanakan konsep pemasaran koperasi yang berorientasi kepada konsumen tidaklah semata-mata berusaha memenuhi kebutuhan dan keinginan langganan saja pada tingkat biaya seberapapun, sehingga merugikan koerai. Dalam pelaksanaan konsep pemasaran ini, yang penting adalah tidak hanya sekedar ingin menyenangkan para langganan/ konsumen, tetapi harus lebih dari itu, yaitu harus mampu memberikan alat bagi pemecahan masalah yang dihadapi oleh para langganan/ konsumen.

Proses pelayanan yang baik selalu berkonsentrasi untuk menciptakan kinerja tertinggi. Untuk itu, seluruh sifat dan perilaku terbaik harus mampu berkolaborasi dan berkoordinasi secara profesional agar dapat memuaskan pelanggan. Intuisi dan empati harus dijadikan sebagai kekuatan dalam memberikan layanan dengan akurasi dan kecepatan terbaik. Intuisi dan empati dimanfaatkan untuk mengantisipasi kebutuhan, mengetahui jawaban atas pertanyaan-pertanyaan pelanggan, melakukan interaksi dan komunikasi terbaik, serta untuk memberikan layanan dengan kualitas prima.

Kemampuan koperasi dalam hal ini koperasi karya bahari untuk menyatukan kekuatan intuitif dan empati ke dalam kekuatan rasional dapat menciptakan karakter layanan yang unggul. Kekuatan rasional haruslah digunakan agar standar dan sistem pelayanan dapat berjalan secara profesional. Sedangkan, kekuatan intuisi dan empati sangat diperlukan agar koperasi bisa menciptakan sikap, sifat, perilaku, dan karakter pelayanan yang memudahkan koperasi untuk terhubung dengan pelanggan perusahaan. Jadi, koperasi mampu tampil fleksibel dengan mengandalkan insting pelayanan dari perusahaan.

Intuisi dan empati Anda yang baik mampu berinteraksi dan berkomunikasi kepada pelanggan dengan sikap terbaik. Jelas, hal ini menjadikan Anda mampu bekerja dan memberikan layanan dengan tepat, cepat, akurat, berkualitas, benar, dan etis. Dan, Anda juga mampu melakukan yang terbaik, mengetahui apa yang boleh dan apa yang tidak boleh, mampu memberikan layanan sesuai harapan, mampu memiliki sikap dan perilaku sesuai harapan, dan mampu tampil sepenuh hati untuk memberikan kinerja terbaik bagi perusahaan Anda.

Dengan memiliki intuisi dan empati yang baik, Anda menjadi pribadi yang mengerti untuk memberikan layanan terbaik tanpa harus menggunakan buku petunjuk. Insting Anda dan perasaan Anda mampu memahami harapan dan kebutuhan pelanggan, sehingga mampu bergerak cepat untuk memberikan layanan berkualitas sesuai harapan pelanggan.

Intuisi dan empati Anda mampu menghasilkan perhatian dan kepedulian, sehingga walaupun menghadapi kesulitan dalam pelayanan, Anda dengan kesabaran dan ketenangan mampu memberikan layanan terbaik sampai bisa membantu pelanggan dengan solusi terbaik. Anda pasti menerima pelanggan walau belum ada solusi untuk mereka. Anda tidak akan membiarkan pelanggan pergi tanpa layanan dan bantuan. Anda selalu tampil 
optimis dan berbicara positif kepada pelanggan Anda, serta mampu menawarkan saran yang bermanfaat. Anda sabar dan tenang menerima keluhan atau ketidakpuasan pelanggan untuk tujuan perbaikan.

Intuisi dan empati Anda menjadikan layanan Anda penuh disiplin untuk memberikan pelayanan terbaik. Anda sadar untuk melakukan yang terbaik dengan kerja keras Anda. Anda sadar untuk menghormati pelanggan dan tidak mau berargumen demi kemenangan opini Anda. Anda selalu rendah hati dan fokus untuk memberikan pengalaman yang indah kepada pelanggan melalui layanan terbaik Anda. Anda selalu ingat dan sadar bahwa pelanggan adalah hadiah terbaik untuk kesuksesan bisnis Anda.

Tentunya koperasi harus mulai dengan langkah awal dengan melakukan pendefenisian atau perumusan macam kebutuhan langganan/ konsumen yang ingin dipenuhi, khususnya ditinjau secara fungsional.

\section{Simpulan}

Efektivitas pelayanan penjualan tiket penyeberangan dari bangsal menuju tiga gili sudah dikatakan cukup efektif terlihat dari beberapa indikator-indikator penunjang pelayanan publik yaitu Reliability(Pelayanan yang diberikan oleh koperasi karya bahari respon masyarakat cenderung kepada hal yang positif itu dikarenakan pelayanan yang diberikan oleh koperasi karya bahri telah memberikan pelayanan yang terbaik, Tangibles(penampilan sarana dan prasarana fisik perusahaan dan keadaan lingkungan sudah sangat terlihat nyata dari pelayanan yang diberikan oleh kopersi karya bahari,responsiveness (ketanggapan seorang karyawan dalam memberikan pelayanan tiket sudah menunjukkan pelayanan yang cepat, assurance (Dalam memberikan pelayanan koperasi karya bahari sudah menunjukkan etika yang baik,dan empathy(sikap kontak personel maupun perusahaan untuk memahami kebutuhan maupun kesulitan konsumen/pelanggan pada Koperasi karya bahari.) .

\section{Saran}

Saran yang disampaikan oleh penulis adalah sebagai berikut :

1. Meningkatkan kemampuan para pegawai dalam melaksanakan pelayanan penjualan tiket pada koperasi karya bahari
2. Meningkatkan pengembangan manejemen koperasi sebagai bahan evaluasi bagi koperasi dalam menganalisis dan mengambil kebijakan dalam memberikan pelayanan bagi pelanggan.

\section{Daftar Pustaka}

[1] Hardiyansyah. 2011. Kualitas Pelayanan Publik. Yogyakarta: Penerbit Gava

[2] Kotler, Philip dan Kevin Lane Keller.2008. Manajemen Pemasaran. Jakarta: Erlangga

[3] Makmur, Syarif. 2008. Pemberdayaan Sumber Daya Manusia dan Efektivitas Organisasi. Jakarta: PT. Raja Grafindo Persada

[4] Makmur. 2011. Efektivitas Kebijakan Kelembagaan Pengawasan. Bandung: PT. Refika Aditama

[5] Moleong, Lexi J. 2012 .Metodelogi Penelitian Kualitatif. PT Remaja Rosdakarya Offset: Bandung

[6] Nawawi, Hadari. 2006. Instrumen Penelitian Bidang Sosial. Yogyakarta: Gadjah Mada University Press

[7] Pasolong, Tjiptono. 2010. Teori Administrasi Publik. Bandung: Alfabeta

[8] Riduwan. 2012. Dasar-dasar Statistika. Bandung: Alfabeta

[9] Sinambela, Poltak Lijan. 2008. Reformasi Pelayanan Publik. Jakarta: PT. Bumi Aksara

[10] Sugiyono. 2009. Metode Penelitian Kuantitatif Kualitatif dan R\&D. Bandung: CV. Alfabeta

[11]Surjadi. 2009. Pengembangan Kinerja Pelayanan Publik. Bandung: PT. Refika Aditama

[12] Suyanto, Bagong \& Sutinah. 2007. Metode Penelitin Sosial. Jakarta: Kencana

[13] Tangkilisan, Hessel Nogi S. 2005. Manajemen Publik. Jakarta: PT. Grasindo 